\title{
ASIDE
}

\section{THE COMMON LAW ORIGINS OF THE INFIELD FLY RULE}

The $^{1}$ Infield Fly Rule ${ }^{2}$ is neither a rule of law nor one of equity; it is a rule of baseball. ${ }^{3}$ Since the ${ }^{4} 1890$ 's it has been a part of the body of the official rules of baseball. ${ }^{5}$ In its inquiry

\footnotetext{
111 Oxford English Dictionary 257-60 (1961).

2 OfF. R. BAseball $2.00 \& 6.05(\mathrm{e})$. Rule 2.00 is definitional in nature and provides
} that:

An INFIELD FLY is a fair fly ball (not including a line drive nor an attempted bunt) which can be caught by an infielder with ordinary effort, when first and second, or first, second and third bases are occupied, before two are out. The pitcher, catcher, and any outfielder who stations himself in the infield on the play shall be considered infielders for the purpose of this rule.

When it seems apparent that a batted ball will be an Infield Fly, the umpire shall immediately declare "Infield Fly" for the benefit of the runners. If the ball is near the baselines, the umpire shall declare "Infield Fly, if Fair."

The ball is alive and runners may advance at the risk of the ball being caught, or retouch and advance after the ball is touched, the same as on any fly ball. If the hit becomes a foul ball, it is treated the same as any foul.

NOTE: If a declared Infield Fly is allowed to fall untouched to the ground, and bounces foul before passing first or third base, it is a foul ball. If a declared Infield Fly falls untouched to the ground outside the baseline, and bounces fair before passing first or third base, it is an Infield Fly.

Rule 6.05 (e) gives operational effect to the definition, by providing that the batter is out when an Infield Fly is declared.

Depending upon the circumstances, other rules which may or may not apply to a particular situation include, inter alia, Fed. R. Crv. P., Rule Against Perpetuities, and Rule of Matthew 7:12 \& Luke 6:31 (Golden).

"Although referred to as "Rules" both officially and in common parlance, if the analogy between the conduct-governing strictures of baseball and a jurisprudential entity on the order of a nation-state is to be maintained, the "rules" of baseball should be considered to have the force, effect, and legitimacy of the statutes of a nation-state. The analogy would continue to this end by giving the "ground rules" of a particular baseball park the same status as the judge-made rules of procedure of a particular court.

${ }^{4}$ Note 1 supra.

${ }^{5}$ It is only with the greatest hesitation that one hazards a guess as to the year of origin of the Infield Fly Rule. Seymour considers it to have been 1893. 1 H. SEYMour, BASEBALL 275 (1960). Richter, on the other hand, in an opinion which The Baseball Encyclopedia joins, considers the rule to have entered the game in 1895 . F. Richter, Richter's History and Records of Baseball 256 (1914); The Baseball Encyclopedia 1526-27 (1974). Finally, Voigt considers 1894 the correct year. 1 D. VoIGt, AMrerican BASEBALL 288 (1966).

Although independent investigation of primary sources has led to the belief that the 
into the common law origins ${ }^{6}$ of the rule, this Aside does not seek to find a predecessor to the rule in seventeenth-century England. The purpose of the Aside is rather to examine whether the same types of forces that shaped the development of the common law ${ }^{7}$ also generated the Infield Fly Rule.

As a preliminary matter, it is necessary to emphasize that baseball is a game of English origin, rooted in the same soil from which grew Anglo-American law and justice. ${ }^{8}$ In this respect it is like American football and unlike basketball, a game that sprang fully developed from the mind of James Naismith. ${ }^{9}$ The story of Abner. Doubleday, Cooperstown, and 1839, a pleasant tribute to American ingenuity enshrined in baseball's Hall of Fame, is not true. ${ }^{10}$ The myth reflects a combination of economic opportunism, ${ }^{11}$ old friendship, ${ }^{12}$ and not a small element of antiBritish feeling. ${ }^{13}$ The true birthplace of the game is England;

rule first developed in 1894 and 1895 , notes $25-35$ infra \& accompanying text, a certain sense of justice would be satisfied if the rule developed as a result of play during the 1894 season. For that season was the first of the championship seasons of the Baltimore Orioles, the team that developed what is now known as "inside baseball," including such plays as the Baltimore chop and the hit-and-run. The Orioles not only played smart baseball; they played dirty baseball. "Although they may not have originated dirty baseball they perfected it to a high degree. In a National League filled with dirty players they were undoubtedly the dirtiest of their time and may have been the dirtiest the game has ever known." D. WALlop, Basebali: AN Informal History 88 (1969); accord, L. Allen, The National League Story 68 (1961); see R. Smith, Baseball 136-46 (1947). Even if the Infield Fly Rule was not developed as a result of the event of the 1894 season, perhaps it should have been.

${ }^{6}$ For a discussion of origins, see generally Scopes v. State, 154 Tenn. 105, 289 S.W. 363 (1927); Genesis 1:1-2:9. But see even more generally Epperson v. Arkansas, 393 U.S. 97 (1968); R. Ardrey, African Genesis (1961); C. Darwin, The Descent of Man (1871); C. DaRwin, The Origin OF SPECIES (1859).

7 For a discussion of common law in a non-baseball context, see W. Holdsworth, A History of English Law (1903-1938); O.W. Holmes, The Common Law (1881).

${ }^{8}$ Cf. Palko v. Connecticut, 302 U.S. 319, 325 (1937).

9 R. Brasch, How Did SPORTS Begin? 41 (1970).

10 R. Henderson, Bat, Ball, and Bishop 170-94 (1947). The Doubleday theory of origin is outlined in 84 CoNG. REC. 1087-89 (1939) (remarks of Congressman Shanley) (semble). Congressional approval of the theory, however, was never forthcoming. H.R.J. Res. 148, 76th Cong., 1st Sess. (1939), seeking to designate June 12, 1939, National Baseball Day, was referred to the Committee on the Judiciary, never again to be heard from. 84 Cong. Rec. 1096 (1939). Nor did the Supreme Court formally adopt the Doubleday theory. Flood v. Kuhn, 407 U.S. 258, 260-61 (1972) (opinion of Blackmun, J.) (not explicitly rejecting the theory either). An interesting, if unlikely, explanation, offerable as an alternative to both the Doubleday and English theories of origin, is found in J. HART, HEy! B.C. 26 from the back (unpaginated, abridged \& undated ed.).

11 R. BRASCH, supra note 9 , at 31-32.

12 R. Henderson, supra note 10 , at 179 . The chairman of the commission suggested by A.G. Spalding to investigate the origins of the game was A.G. Mills, who had belonged to the same military post as Abner Doubleday.

${ }^{13} \mathrm{R}$. SMITH, supra note 5 , at 31. 
thence it was carried to the western hemisphere, to develop as an American form. ${ }^{14}$

The original attitude toward baseball developed from distinctly English origins as well. The first "organized" games were played in 1845 by the Knickerbocker Base Ball Club of New York Gity, ${ }^{15}$ and the rules which governed their contests clearly indicate that the game was to be played by gentlemen. Winning was not the objective; exercise was. ${ }^{16}$ "The New York club players were 'gentlemen in the highest social sense'-that is, they were rich. ... The earliest clubs were really trying to transfer to our unwilling soil a few of the seeds of the British cricket spirit." 17 This spirit, which has been variously described as the attitude of the amateur, of the gentleman, and of the sportsman, ${ }^{18}$ would have kept the rules simple and allowed moral force to govern the game. ${ }^{19}$ Such an attitude, however, was unable to prevail.

As baseball grew, so did the influence of values that saw winning, rather than exercise, as the purpose of the game. ${ }^{20}$ Victory was to be pursued by any means possible within the language of the rules, regardless of whether the tactic violated the spirit of the rules. ${ }^{21}$ The written rules had to be made more and more specific, in order to preserve the spirit of the game. ${ }^{22}$

The Infield Fly Rule is obviously not a core principle of baseball. Unlike the diamond itself or the concepts of "out" and "safe," the Infield Fly Rule is not necessary to the game. Without the Infield Fly Rule, baseball does not degenerate into bladderball ${ }^{23}$ the way the collective bargaining process degener-

${ }^{14}$ See generally H. SEymour, supra note 5; D. VoIGT, supra note 5. The American qualities of the game are also revealed in other than historical or legal contexts. $C f$. $M$. Gardner, The Annotated Gasey at the Bat (1967); B. Malamud, The Natural. (1952).

${ }^{15} \mathrm{R}$. SMITH, supra note 5, at 32-35.

${ }^{16}$ KNickerbocker Base Ball Club R. 1 (1845), reprinted in R. Henderson, supra note 10, at 163-64, and in F. RichTER, supra note 5, at 227.

${ }^{17}$ R. SMITH, supra note 5 , at 37.

${ }^{18}$ Keating, Sportsmanship as a Moral Category, 75 EтHIcs 25, 33 (1964).

${ }^{19}$ R. SMITH, supra note 5 , at 68-69.

${ }^{20}$ I D. VoIGHT, supra note 5, at xvii; $c f$. Hearings on S. 3445, Federal Sports Act of 1972, Before the Senate Committee on Commerce, 92d Cong., 2d Sess. 94-95 (1973) (statement of H. Cosell). See generally Keating, supra note 18, at 31-34.

${ }^{21}$ Perhaps the most glaring example of this attitude is contained in the career of Mike "King" Kelly. When the rules permitted substitutions on mere notice to the umpire, Kelly inserted himself into the game after the ball was hit in order to catch a ball out of reach of any of his teammates. R. SMITH, supra note 5, at 89-90.

${ }^{22} C f$. id. 68-69; I D. Vorct, supra note 5, at 204-05.

${ }^{23}$ See Yale Daily News, Oct. 29, 1966, at 1, col. 1. 
ates into economic warfare when good faith is absent. ${ }^{24}$ It is a technical rule, a legislative response to actions that were previously permissible, though contrary to the spirit of the sport.

Whether because the men who oversaw the rules of baseball during the 1890's were unwilling to make a more radical change than was necessary to remedy a perceived problem in the game, or because they were unable to perceive the need for a broader change than was actually made, three changes in the substantive rules, stretching over a seven-year period, were required to put the Infield Fly Rule in its present form. In each legislative response to playing field conduct, however, the fundamental motive for action remained the same: "To prevent the defense from making a double play by subterfuge, at a time when the offense is helpless to prevent it, rather than by skill and speed." 25

The need to enforce this policy with legislation first became apparent in the summer of 1893. In a game between New York and Baltimore, with a fast runner on first, a batter with the "speed of an ice wagon" 26 hit a pop fly. The runner stayed on first, expecting the ball to be caught. The fielder, however, let the ball drop to the ground, and made the force out at second. ${ }^{27}$ The particular occurrence did not result in a double play, but that possibility was apparent; it would require only that the ball not be hit as high. Although even the Baltimore Sun credited the New York Giant with "excellent judgment," ${ }^{28}$ the incident suggested that something should be done, because by the play the defense obtained an advantage that it did not deserve and that the offense could not have prevented. Umpires could handle the situation by calling the batter out, ${ }^{29}$ but this was not a satisfactory solution; it could create as many problems as it solved. ${ }^{30}$ The 1894 winter meeting responded with adoption of the "trap ball"

${ }^{24}$ NLRB v. Insurance Agents Int'l Union, 361 U.S. 477, 488-90 (1960).

$251 \mathrm{H}$. SeYmour, supra note 5, at 276.

${ }^{26}$ Baltimore Sun, May 24, 1893, at 6, col. 2. Raised by this statement is the issue of the speed of an ice wagon in both relative and absolute terms. Such inquiry is beyond the scope of this Aside.

${ }^{27} I d$. The fielder who made the play was Giant shortstop and captain John Montgomery Ward, who became a successful attorney after his playing days ended. $1 \mathrm{D}$. VoIGT, supra note 5, at 285.

${ }^{28}$ Baltimore Sun, May 24, 1893, at 6, col. 2.

${ }^{29}$ E.g., the Chicago-Baltimore game of June 8, 1893. "In the second inning . . . Kelley hit a pop fly to short-stop. Dahlen caught the ball, then dropped it and threw to second base, a runner being on first. The muff was so plain that Umpire McLaughlin refused to allow the play and simply called the batsman out." Baltimore Sun, June 9, 1893 , at 6 , col, 2.

${ }^{30}$ Text accompanying notes $45-46$ infra. 
rule, putting the batter out if he hit a ball that could be handled by an infielder while first base was occupied with one out. ${ }^{31}$

The trap ball rule of 1894, however, did not solve all problems. First, although the rule declared the batter out, there was no way to know that the rule was in effect for a particular play. The umpire was not required to make his decision until after the play, and, consequently, unnecessary disputes ensued..$^{32}$ Second, it became apparent that the feared unjust double play was not one involving the batter and one runner, but one that, when two men were on base, would see two baserunners declared out. ${ }^{33}$ The 1895 league meeting ironed out these difficulties through changes in the rules. ${ }^{34}$ The third problem with the trap ball rule of 1894, one not perceived until later, was that it applied only when one man was out. The danger of an unfair double play, however, also exists when there are no men out. This situation was corrected in 1901, and the rule has remained relatively unchanged since that time. ${ }^{35}$

The Infield Fly Rule, then, emerged from the interplay of four factors, each of which closely resembles a major force in the development of the common law. First is the sporting approach to baseball. A gentleman, when playing a game, does not act in a manner so unexpected as to constitute trickery; ${ }^{36}$ in particular he does not attempt to profit by his own unethical conduct. ${ }^{37}$

${ }^{31}$ Baltimore Sun, Feb. 27, 1894, at 6, col. 3. The rule stated that "the batsman is out if he hits a fly ball that can be handled by an infielder while first base is occupied and with only one out." Id. Apr. 26, 1894, at 6, col. 2.

${ }^{32}$ Baltimore Sun, Apr. 26, 1894, at 6n col. 2.

${ }^{33} 1 \mathrm{H}$. SeYmour, supra note 5, at 275-76. Seymour developed yet another reason for the change in the rule: that "teams got around it by having outfielders come in fast and handle the pop fly." Id. 276. This does not appear to be a valid thesis because, from the beginning, the rule referred not to whether an infielder, as opposed to an outfielder, did handle the chance, but to whether an infielder could handle it. Note 31 supra.

${ }^{34}$ Baltimore Sun, Feb. 18, 1895, at 6, col. 4. Id. Feb. 28, 1895, at 6, col. 5 .

${ }^{35}$ The Baseball Encyclopedia 1527 (1974). The current rule is set forth in note 2 supra.

${ }^{36}$ See, e.g., Pluck (the wonder chicken).

37 In the law, this belief is reflected in the clean hands doctrine, which "is rooted in the historical concept of [the] court of equity as a vehicle for affirmatively enforcing the requirements of conscience and good faith." Precision Instrument Mfg. Co. v. Automotive Maintenance Mach. Co., 324 U.S. 806, 814 (1945). For a statutory codification of the clean hands rule, see Cal. Health \& SAfETy Code $\$ 28548$, II 2 (West 1967) (requiring food service employees to "clean hands" before leaving restroom). See generally $\mathrm{Z}$. CHAFEE, Some Problems of EQuity, chs. 1-3 (1950).

To be contrasted with the doctrine of "clean hands" is the "sticky fingers" doctrine. The latter embodies the reaction of the baseball world to the excitement caused by the emergence of the home run as a major aspect of the game. Applying to the ball a foreign substance, such as saliva, made the big hit a difficult feat to achieve. As a result, in 1920, the spitball was outlawed. L. Al.LEN, supra note 5, at 167 . The banning of the spitball was 
The gentleman's code provides the moral basis for the rule; it is the focal point of the rule, just as the more general precept of fair play provides a unifying force to the conduct of the game. The principle of Anglo-American law analogous to this gentleman's concept of fair play is the equally amorphous concept of due process, or justice ${ }^{38}$ itself.

Baseball's society, like general human society, includes more than gentlemen, and the forces of competitiveness and professionalism required that the moral principle of fair play be codified so that those who did not subscribe to the principle would nonetheless be required to abide by it. ${ }^{39}$ Thus the second factor in the development of the Infield Fly Rule-a formal and legalistic code of rules ensuring proper conduct-was created. ${ }^{40}$ In the common law, this development manifested itself in the formalism of the writ system. ${ }^{41}$ Conduct was governed by general principles; but to enforce a rule of conduct, it was necessary to find a remedy in a specific writ. ${ }^{42}$ The common law plaintiff had no remedy if the existing writs did not encompass the wrong complained of; and the baseball player who had been the victim of a "cute" play could not prevail until the umpire could be shown a rule of baseball squarely on point.

To the generalization set forth in the preceding sentence there is an exception, both at common law and at baseball. At common law, the exception was equity, which was able to aid the plaintiff who could not find a form of action at law. ${ }^{43}$ At baseball, the exception was the power of the umpire to make a

not, however, absolute. Seventeen pitchers were given lifetime waivers of the ban, id., possibly because the spitball had become an essential element of their stock-in-trade, and depriving them of the pitch would in effect deny them the right to earn a living. See Adams v. Tanner, 244 U.S. 590 (1917); McDermott v. City of Seattle, 4 F. Supp. 855, 857 (W.D. Wash. 1933); Winther v. Village of Weippe, 91 Idaho 798, 803-04, 430 P.2d 689, 694-95 (1967); $f$. Restatement (Second) of Contracts \& 90 (Tent. Drafts Nos. 1-7, 1973). But see Ferguson v. Skrupa, 372 U.S. 726, 730-31 (1963).

${ }^{38}$ See generally, e.g., U.S. Const. amends. V \& XIV and cases citing thereto; Poe v. Ullman, 367 U.S. 497, 539-55 (1961) (Harlan, J., dissenting); J. RAwLS, A THEORY OF Justice (1971); Bentley, John Rawls: $A$ Theory of Justice, 121 U. PA. L. Rev. 1070 (1973); Michelman, In Pursuit of Constitutional Welfare Rights: One View of Rawls' Theory of Justice, 121 U. PA. L. Rev. 962 (1973); Scanlon, Rawls' Theory of Justice, 121 U. PA. L. Rev. 1020 (1973); $c f$. , e.g., Byron R. "Whizzer" White (1962- ), Hugo L. Black (1937-71), \& Horace Gray (1881-1902) (Justices). But cf., e.g., Roger B. Taney (1836-64) (Chief Justice).

${ }^{39}$ Keating, supra note 18 , at 30 . See also R. SMITH, supra note 5 , at 68-69.

40 Text accompanying notes 25-35 supra.

412 F. Maitland, Collected Papers 477-83 (1911).

12 F. Pollock, The Genius of the Common Law 13 (1912); 2 F. Pollock, \& F. Maitland, History of English Law 558-65 (2d ed. 1952).

${ }^{43}$ F. Maitland, EQUiTy 4-5 (1909). 
call that did not fit within a particular rule. ${ }^{44}$ The powers of equity and of the umpire, however, were not unlimited. The law courts circumscribed the power of the chancellor to the greatest extent possible, and this process of limitation has been defended. ${ }^{45}$ Likewise, the discretionary power of the umpire has been limited: Additions to the written rules have reduced the area within which the umpire has discretion to act. Strong policy reasons favor this limitation upon the umpire's discretionary power. Because finality of decision is as important as correctness of decision, an action that invites appeal, as broad discretion in the umpire does, is not valued. The umpire must have the status of an unchallengeable finder of fact. ${ }^{46}$ Allowing challenges to his authority on matters of rules admits the possibility that he may be wrong, and encourages a new generation of challenges to findings of fact.

The fourth element in the development of the Infield Fly Rule is demonstrated by the piecemeal approach that rules committees took to the problem. They responded to problems as they arose; the process of creating the Infield Fly Rule was incremental, with each step in the development of the rule merely a refinement of the previous step. Formalism was altered to the extent necessary to achieve justice in the particular case; it was not abandoned and replaced with a new formalism. AngloAmerican law has two analogies to this process. The first is the way in which common law precedents are employed to mold existing remedies to new situations. Although the rigid structure of the common law was slow to change, it did change. The substantive change took place not only as a result of judicial decision; it was also caused by legislation, which is the second analogy. The legislation, however, was to a great extent directed at specific defects perceived to exist in the system. ${ }^{47}$ Adjustment of the law, not its reform, was the goal of the legislative process. The rules of baseball and of Anglo-American jurisprudence are thus to be contrasted with the continental system of complete codes designed to remedy society's ills with a single stroke of the legislative brush. ${ }^{48}$

The dynamics of the common law and the development of one of the most important technical rules of baseball, although

\footnotetext{
44 Note 29 supra.

45 2 F. Maitland, supra note 41 , at 491-94.

46 Off. R. Baseball 4.19.

${ }^{47}$ F. Pollock, supra note 42, at 72.

${ }^{48} C f$. H. Gutteridge, Comparative Law 77-78 (2d ed. 1949).
} 
on the surface completely different in outlook and philosophy, share significant elements. Both have been essentially conservative, changing only as often as a need for change is perceived, and then only to the extent necessary to remove the need for further change. Although problems are solved very slowly when this attitude prevails, the solutions that are adopted do not create many new difficulties. If the process reaps few rewards, it also runs few risks. 